\title{
Late Titus Phase Sites Along Caney Creek in Northern Wood County, Texas
}

Mark Walters

Heritage Research Center, Stephen F. Austin State University

Follow this and additional works at: https://scholarworks.sfasu.edu/ita

Part of the American Material Culture Commons, Archaeological Anthropology Commons, Environmental Studies Commons, Other American Studies Commons, Other Arts and Humanities Commons, Other History of Art, Architecture, and Archaeology Commons, and the United States History Commons

Tell us how this article helped you.

This Article is brought to you for free and open access by the Center for Regional Heritage Research at SFA ScholarWorks. It has been accepted for inclusion in Index of Texas Archaeology: Open Access Gray Literature from the Lone Star State by an authorized editor of SFA ScholarWorks. For more information, please contact cdsscholarworks@sfasu.edu. 


\section{Late Titus Phase Sites Along Caney Creek in Northern Wood County, Texas}

Creative Commons License

(c) (i) (9)

This work is licensed under a Creative Commons Attribution-NonCommercial 4.0 International License 


\section{LATE TITUS PHASE SITES ALONG CANEY CREEK IN NORTHERN WOOD COUNTY, TEXAS}

\section{Mark Walters}

There are a number of seemingly late Titus phase (ca. after A.D. 1670) Caddo sites clustered on the middle to upper reaches of Caney Creek in northern Wood County (Figure 1) This is based on a large collection of grave goods amassed by a collector in the 1960s from Caddo sites in this area. No European goods were reported from any of the sites but several of the vessel types have been shown to often occur in association with a few European trade goods at other published Caddo sites (i.e., Taylor Engraved, Keno Trailed, Hodges Engraved, Simms Engraved, and Womack Engraved) (Schambach and Miller 1984). There are examples in the collection of Ripley Engraved carinated bowls with inverted rims (and often with red-filming) that seem to indicate a transition from Ripley Engraved scrolls to motifs such as ticked horizontal lines also seen on historic Caddo pottery types Natchitoches Engraved and Patton Engraved.

There are also elements from the Caney Creek collection similar to Taylor Engraved with scrolls with hooked arms separated by a short gap (Figure 2a) that have been described as Womack Engraved (Duffield and Jelks 1961: Figure 10) at the Pearson site on the Sabine River, an $18^{\text {th }}$ century aboriginal site in Rains County, Texas. These examples closely resemble examples from the Culpepper site in Hopkins County, another late Titus phase site that also has not yielded any European goods (Scurlock 1962: Figure 5h-i). Scurlock called these vessels Womack Engraved, but they lack the tick marks characteristic of the type (Harris et al. 1965: Figure 6b, d). The addition of tick marks to inverted rim Taylor Engraved vessels, including vessels with ticked semi-circles (Figure 2b) would complete the stylistic transition from Taylor Engraved to Womack Engraved. These seemingly apparent transitions in ceramic styles from Ripley Engraved and Taylor Engraved (even Hodges Engraved, see Harris et al. 1965: Figure 6b) into types such as Womack Engraved-along with the more frequent use of horizontal ticked engraved lines noted on historic ceramic types (Patton Engraved and Natchitoches Engraved) that are closely associated with Historic Caddo groups living in East Texas - raises the distinct possibility that sites like Gilbert or Pearson that have been attributed to Wichitaspeaking groups of the Norteno focus (Jelks 1967) may in fact have been later archaeological manifestations of the Caddo groups living on Caney Creek in the upper Sabine River basin.

The vessels in the collection from the Caney Creek sites had no shell temper other than the Keno Trailed bowl (Figure 3) that was obviously a trade item from the Red River (Walters 1998). At the Gilbert site, shell temper was used in $56 \%$ of the sherds (Jelks 1967), compared to about $24 \%$ at the Pearson site. These differences could be the result of technological changes through time since Gilbert and Pearson probably date 1-2 generations, or more, after the Caney Creek late Titus phase Caddo occupations. Furthermore, these differences in temper use may simply reflect differences in preferences between local groups. 


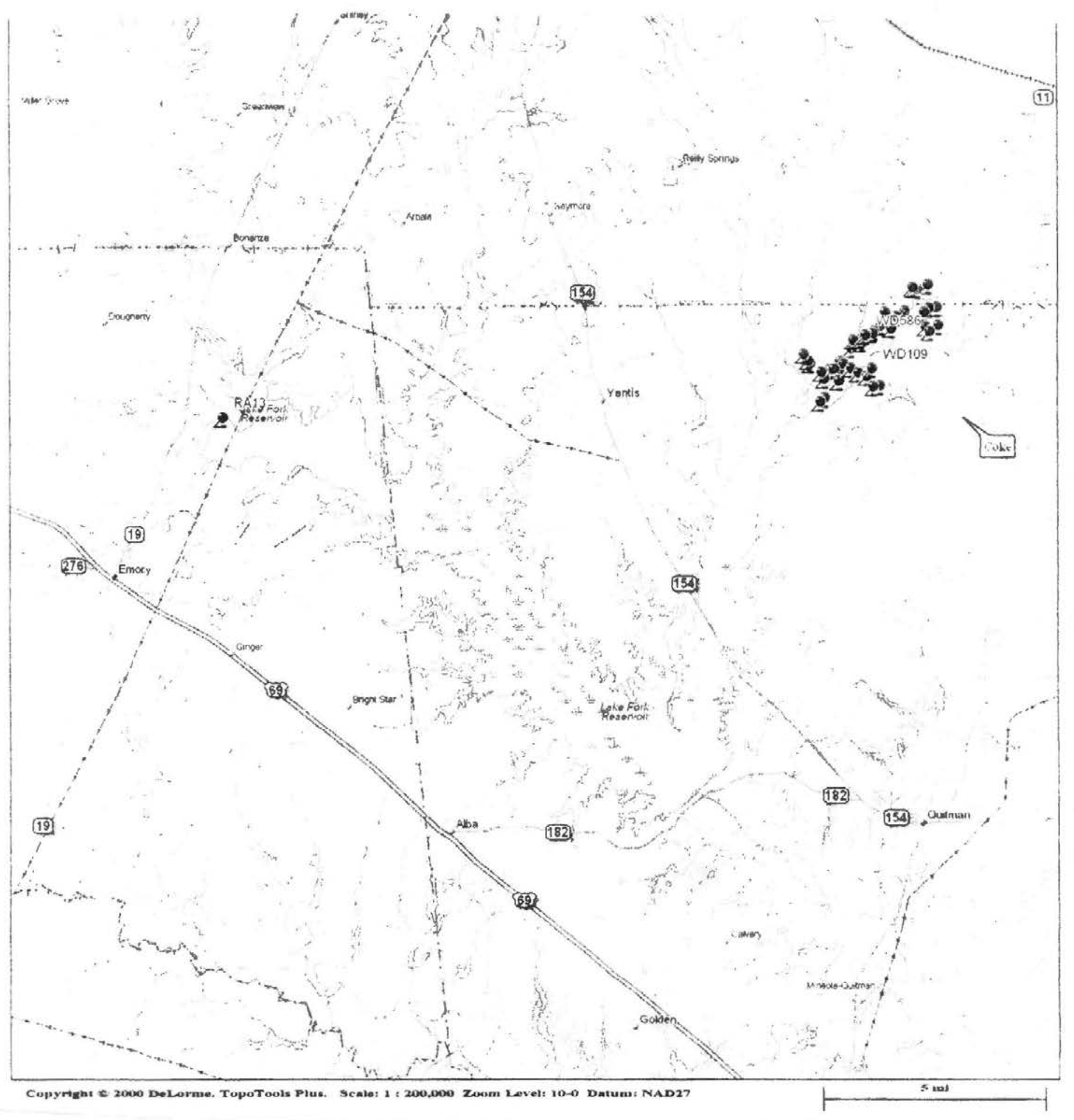

Figure 1. General location of late Titus phase sites along Caney Creek in northern Wood County, Texas. 


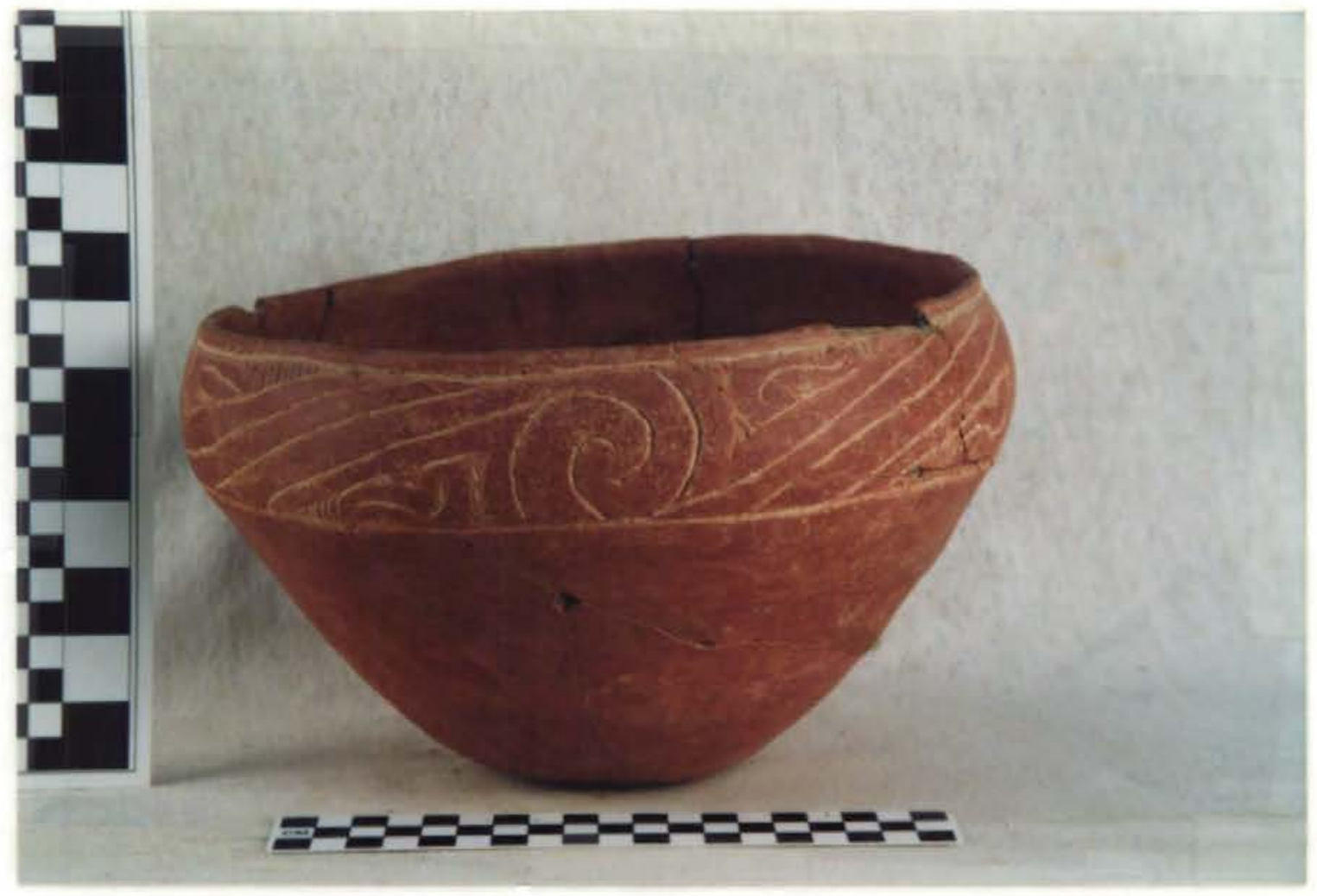

Figure 2a. Inverted rim and red-slipped Taylor Engraved vessel from the Spoonbill site.

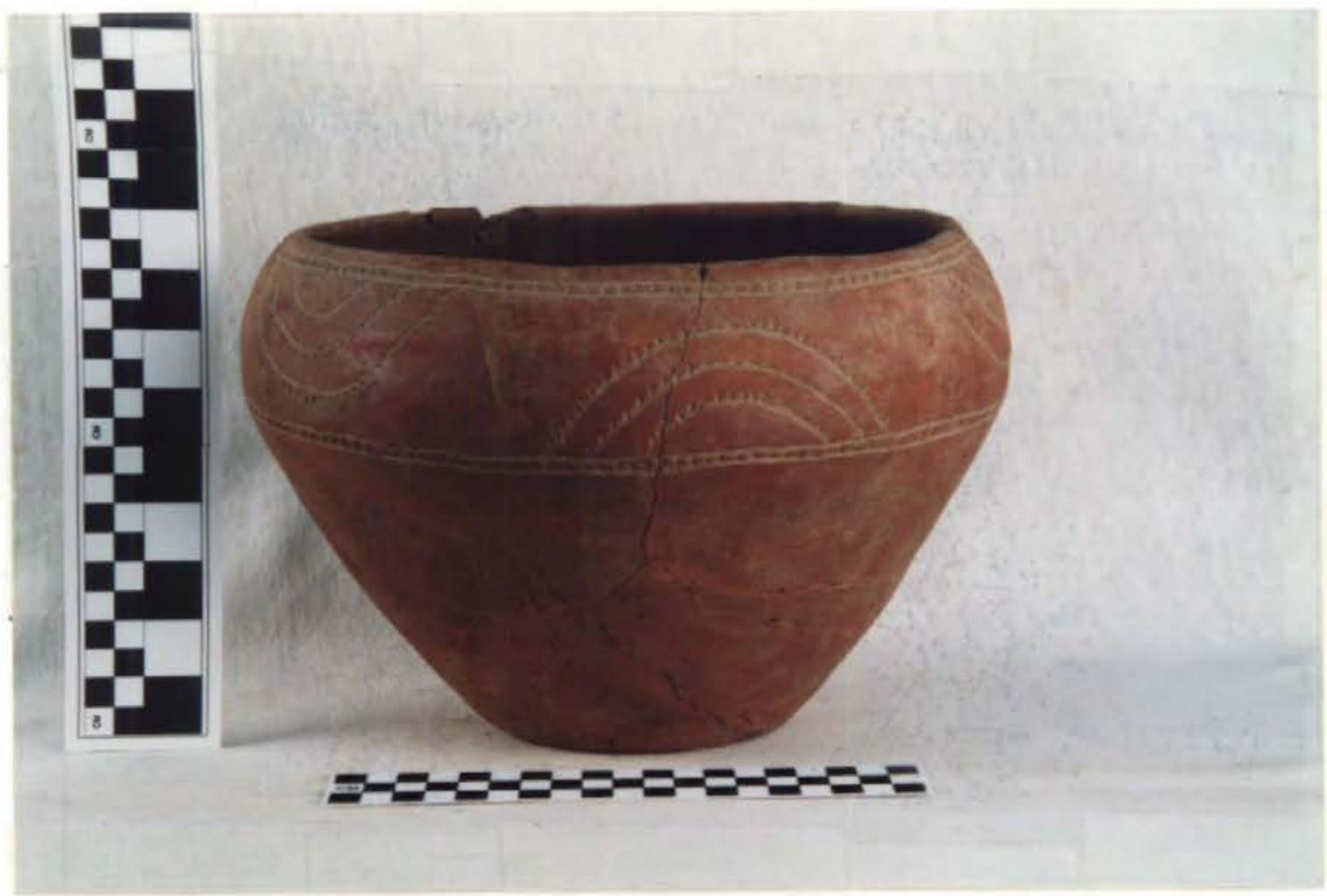

Figure $2 \mathrm{~b}$. Inverted rim and red-slipped vessel with ticked semi-circles. 


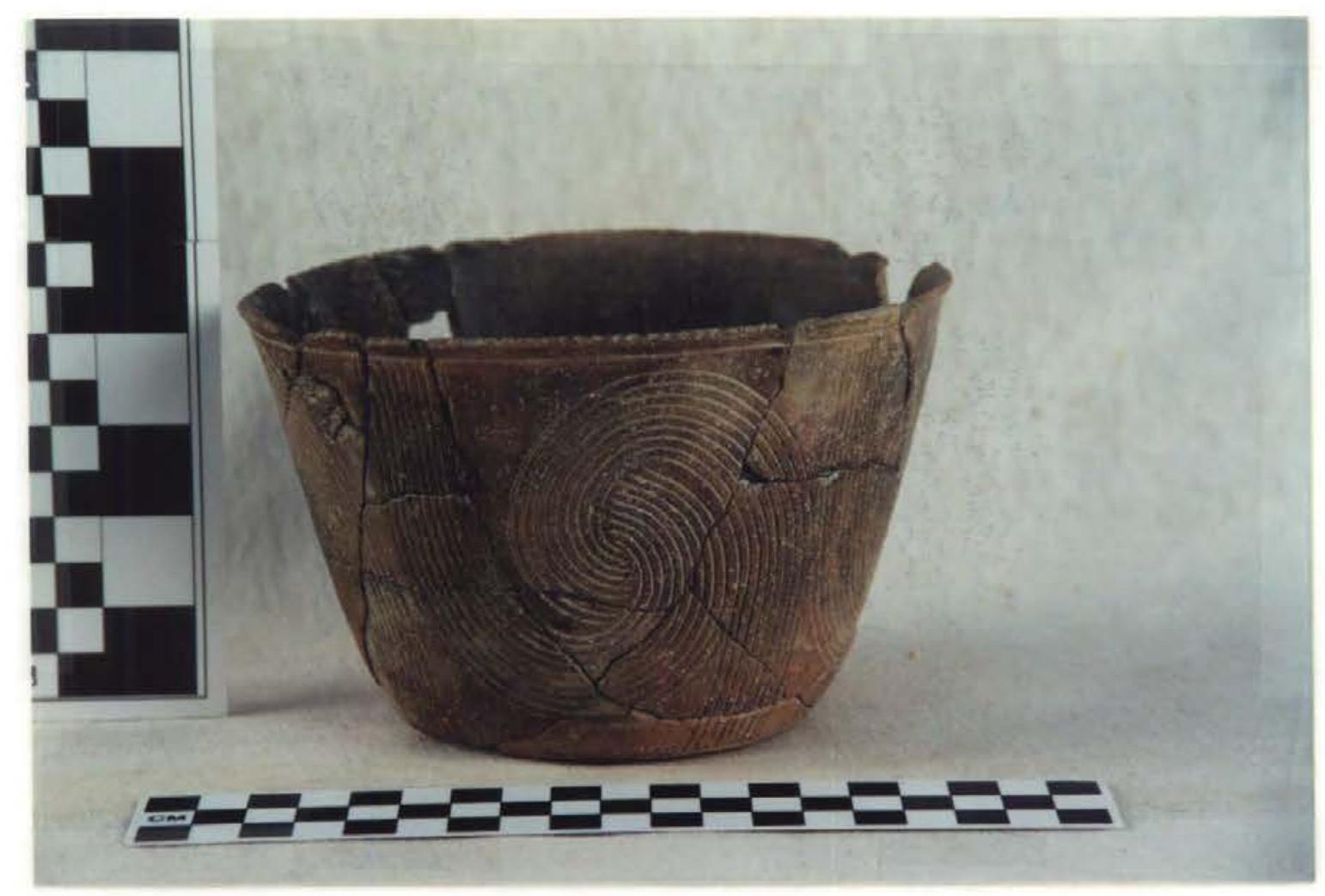

Figure 3. Kcno Trailed vessel from the Spoonbill sitc.

\section{References Cited}

Duffield, Lathel F., and Edward B. Jelks

1961. The Pearson Site: A Hisioric Indian Site in Iron Bridge Reservoir, Rains County, Texas. Archaeology Series, No. 4. The University of Texas, Department of Anthropology, Austin.

Harris, R. King, Inus M. Harris, Jay C. Blaine, and Jerrylee Blaine

1965 A Preliminary Archeological and Documentary Study of the Womack Site, Lamar County, Texas. Bulletin of the Texas Archeological Society 36:287-363.

Jelks, Edward B. (editor)

1967 The Gilbert Site: A Norteno Focus Site in Northeast Texas. Bulletin of the Texas Archeological Sociely 37:1-248. 
Schambach, Frank F. and John E. Miller

1984 A Description and Analysis of the Ceramics. In Cedar Grove: An Interdisciplinary Investigation of a Late Caddo Farmstead in the Red River Valley, edited by N. L. Trubowitz, pp. 109-170. Research Series No. 23. Arkansas Archeological Survey, Fayetteville.

Scurlock, J. Dan

1962 The Culpepper Site, A Late Fulton Aspect Site in Northeastern Texas. Bulletin of the Texas Archeological Sociely 32:285-316.

Waltcrs, Mark

1998 A Keno Trailed Vessel from the Spoonbill Site in Wood County, Texas. Journal of Northeast Texas Archaeology 11:46-48. 